\title{
Student's Perception of Chemistry Department Towards Assessment Approach
}

\author{
Muchlis \\ Chemistry Department, Universitas Negeri Surabaya \\ Surabaya, Indonesia \\ muchlis@unesa.ac.id
}

\author{
Suhadi Ibnu ${ }^{1}$, Subandi ${ }^{2}$ \\ Prof., Graduate School, Universitas Negeri Malang \\ Malang, Indonesia \\ ${ }^{1}$ suhadi.ibnu.fmipa@um.ac.id, 22Subandi.fmipa@um.ac.id
}

\author{
Siti Marfuah \\ Graduate School, Universitas Negeri Malang \\ Siti.marfuah.fmipa@um.ac.id
}

\begin{abstract}
Many researches related students' perception towards assessment types, assessment tasks and classroom assessment environment, but related perception of assessment approach (assessment of learning, assessment for learning, and assessment as learning) seldom be done. The aim of this research was describe students' perception of Chemistry Department towards assessment approach. Number of respondents were 160 students from generation of academics years 2014, 2015 and 2016 of Chemistry Department, FMIPA Universitas Negeri Surabaya, Indonesia. Research instrument was questioner. The questioner was developed myself use four-D Model. Based on amount of student who choose perception towards assessment approach and also score of questioner items, majority of students' perception were "assessment as learning". Based on amount of score respondent, majority of students' perception were "assessment of learning" at number 4, 10 and 12 of questioner item, "assessment for learning" at number 1, 2.3 and 8, and "assessment as learning" at number 5, 6, 7, 9, 11 and 13 .
\end{abstract}

Keywords-. Assessment Approach; four-D Model; Student's Perception

\section{INTRODUCTION}

Assessment is part of learning [12]. Assessment is a process of information collection, and in the context of teaching, this information is typically used to examine and describe students' performance [9]. We assess for the reasons 1) to determine that the intended learning outcomes of the courseware being achieved, 2) to provide feedback to students on their learning, enabling them to improve their performance, 3) to motivate students to undertake appropriate work, 4) to support and guide learning, 5) to describe student attainment, informing decisions on progression and awards, 6) to demonstrate that appropriate standard are being maintained, and 7) to evaluate the effectiveness of teaching [12]. Information related assessment can be collected by informal to formal range, and way to use formative or summative or combined both them [11].

Based on assessment types, assessment divided to 1) oral test, 2) written test, and 3) alternatives test [16]. Based on assessment tasks, assessment divided to 1) congruence with planned learning, 2) authenticity, 3) student consultation, 4) transparency, and 5) diversity [1]. Based on classroom assessment environment, assessment divided to 1) learningoriented assessment environment, and 2) performance-oriented assessment environment [7] and based on assessment approach, assessment divided to 1) assessment of learning, 2) assessment for learning, and 3) assessment as learning [6].

There is a belief that if the assessment process is improved, that the resultant learning will improve [2]. According to Scouller [14], there is strong empirical evidence that students' perceptions of the value and validity of assessment affect their learning. Student' view of upcoming assessments influence their motivation [10]. Perception is 1) ability see, hear, or become aware of something through the sense; 2 ) the way in which something is regarded, understood or interpreted [5]. Perception towards assessment is defined as student behavior recognize assessment in learning research moment conducted [16].

Many researches related students' perception towards assessment types, assessment tasks and classroom assessment environment. An example, Watering, Gijbels, Dochy and Rijt [16] report that there is weak correlation between perceptions of assessment type (oral test, written test, alternatives test) with assessment score. Other example, Alkharusi [1] report that albeit not correlation causality between perceptions of assessment task (congruence with planned learning, authenticity, student consultation, transparency, diversity) with motivation and learning, but this result study can help to understand how do silent aspects of assessment task related meaningful towards motivation and learning. The same way, research of Cheng, $\mathrm{Wu}$, and Liu [17] that study correlation between perceptions of assessment task and classroom assessment environment (learning-oriented assessment environment, performance-oriented assessment environment). The result study Cheng, $\mathrm{Wu}$, and Liu [17] show that congruence with planned learning and student consultation are positive predictor of learning-oriented assessment environment and negative predictor of performance-oriented assessment environment. Whiles no reports of study related students' perception towards assessment approach (assessment of learning, assessment for learning, and assessment as learning). 
Assessment of learning is so mentioned assessment for summative or summative assessment [15]. Assessment of learning is a process collecting and interpreting of evidence for learning summary at periodic time, to make decision of student learning quality based on criteria and mark of value that represented of quality [19]. Summative assessment done at or near end program or learning cycle.

Assessment for learning focus on assessment for formative that procedure at formal and informal range that done by teacher as part of teaching-learning normal process and information use teacher and student to modified and to improve learning and understanding [7]. Assessment for learning offering alternative perspective towards assessment in school, or the simple words assessment for learning shift from summative assessment to formative assessment, from decision taking to create description that it used to decide next step in a students' learning [6].

More recently the phrase Assessment as learning has been used to focus our consideration on assessment as 'student metacognition and as a literacy [7]. Assessment as learning is a process developing and supporting student metacognition skill [19]. Student actively involve in assessment, where they monitor their learning, use feedback from teacher, from themselves and their friends to determine next steps and set individual learning goals [19]. Not comparing student with the others [6]. Assessment as learning make teacher change knowledge bearers to knowledge guides where teacher guide students by to understands "their cognitive process" so students learn monitoring their understanding and make adjustments [13]. Assessment as learning is students reflect their work and make them great role towards their work [6]. According to Earl and Katz [8] say that in assessment as learning, the mind of students about their learning, strategies to support and to advance their learning, and mechanism students to make adjustments and help their learning.

Based on description problem above, this writing focus to describe students' perception of Chemistry Department towards assessment approach. Assessment approach include assessment of learning, assessment for learning and assessment as learning.

\section{METHODS}

This research type was descriptive research. Respondents were student of Chemistry Department at Mathematics and Science Faculty of Universitas Negeri Surabaya. Number of respondents were 160 students from generation of academics years 2014, 2015 and 2016. Research place was in Chemistry Department at Mathematics and Science Faculty of Universitas Negeri Surabaya, Indonesia. Research instrument was questioner. The questioner was developed myself use four-D Model. Before use it, the questioner was validated by professor in Graduate School in Universitas Negeri Malang and Universitas Negeri Surabaya. The result of developing questioner was the questioner can be used. The way collecting data was questioner method. In this research, respondents gave score according to Table I.
TABLE I. RESPONDENT SCORE TOWARDS QUESTIONERS

\begin{tabular}{|c|l|}
\hline Score & \multicolumn{1}{c|}{ Describe } \\
\hline 1 & if most suitable with their choosing \\
\hline 2 & if intermediate suitable with their choosing \\
\hline 3 & if lowest suitable with their choosing \\
\hline
\end{tabular}

Next step, change respondent score according to Table II.

TABLE II. GUIDING CHANGE SCORE RESPONDENT

\begin{tabular}{|c|c|}
\hline Respondent score & Score for Analysis \\
\hline 1 & 3 \\
\hline 2 & 2 \\
\hline 3 & 1 \\
\hline
\end{tabular}

Next step, sum of score for analysis to determine tends respondent' perception. The greatest score for analysis shown students' perception, assessment of learning or assessment for learning or assessment as learning.

\section{RESULT AND DISCUSSION}

Students' perception of Chemistry Department towards assessment approach are presented in Table 3. Based on Table 3 , show that majority of students' perception is assessment as learning. Theoretically perception of "assessment as learning" is better than perception of "assessment for learning" is better than perception of "assessment of learning". This is suitable with result study Mehmood, et al. [18] that student was assessed by assessment for learning have score higher than students was not assessed by assessment for learning. Whiles according to Davies, Pantzopoulus dan Gray [4] that implementing assessment as learning have rich learning experience so enhancing their professional outcome. Only students of PKA 2014 that it was majority assessment for learning. This result was interesting, because many items of questioner not happened in reality. According to dictionary [5], perception is ability to see, hear, or become aware of something through the sense, whiles in reality, key assessor was lecturer, result of learning was written in score not description, and assessment was done in middle or end of semester.

TABLE III. RECAPITULATION OF SCORE KIND OF PERCEPTION PER GENERATION

\begin{tabular}{|c|c|c|c|c|c|}
\hline \multirow{2}{*}{ No. } & \multirow{2}{*}{ Generation } & \multicolumn{3}{|c|}{ Sum of } & \multirow{2}{*}{ Sum } \\
\cline { 3 - 5 } & & AOL & AFL & AAL & \\
\hline 1 & PKA 2014 & 3 & 23 & 6 & 32 \\
\hline 2 & PKA 2015 & 3 & 2 & 30 & 35 \\
\hline 3 & KA 2015 & 0 & 5 & 16 & 21 \\
\hline 4 & KB 2015 & 0 & 9 & 11 & 20 \\
\hline 5 & KA 2016 & 2 & 3 & 21 & 26 \\
\hline 6 & KB 2016 & 0 & 2 & 24 & 26 \\
\hline & Total & 8 & 44 & 108 & 160 \\
\hline
\end{tabular}

With: $\mathrm{AOL}=$ assessment of learning

AFL $=$ assessment for learning

$\mathrm{AAL}=$ assessment as learning

Description clearly of score of questioner items, was shown in Table IV. Based on Table IV, number 4 of questioner item, perception majority was assessment of learning, that it is majority of students understood "assessment result is expressed 
by score", as expressed at Dictionary [5] that perception is the way in which something is regarded, understood or interpreted.

Number 10 of questioner item, perception majority was assessment of learning, that it is majority of students understood something assessed were only key concept, knowledge, skill related learning goals, not what need student to improve their learning. Number 12 of questioner item, perception majority was assessment of learning, that it is majority of students understood kind of assessment that it is implemented in learning was summative not formative.

TABLE IV. SCORE OF QUESTIONER ITEMS

\begin{tabular}{|c|c|c|c|}
\hline $\begin{array}{c}\text { Number of } \\
\text { Questioner } \\
\text { Item }\end{array}$ & $\mathbf{A}$ & $\mathbf{B}$ & $\mathbf{C}$ \\
\cline { 2 - 4 } & 284 & 338 & 279 \\
\hline 1 & 329 & 252 & 291 \\
\hline 2 & 241 & 273 & 334 \\
\hline 3 & 313 & 260 & 309 \\
\hline 4 & 330 & 260 & 292 \\
\hline 5 & 339 & 283 & 216 \\
\hline 6 & 263 & 372 & 257 \\
\hline 7 & 249 & 324 & 308 \\
\hline 8 & 248 & 363 & 272 \\
\hline 9 & 350 & 272 & 260 \\
\hline 10 & 284 & 351 & 258 \\
\hline 11 & 231 & 258 & 332 \\
\hline 12 & 312 & 315 & 250 \\
\hline 13 & AOL, $=$ AFL, $=$ AAL
\end{tabular}

Majority perception towards assessment for learning so happened at number 1, 2, 3 and 8 of questioner items. It means students have perception that assessment is the most important done, assessment was done periodicity before learning finish, as key assessor were student and teacher, and conducting assessment need involvement student. This students 'regarding was important asset to enhancing their learning, because according to [18] that student was assessed by assessment for learning have score higher than students was not assessed by assessment for learning.

Based on Table 4, we look at that for number 5, 6, 7, 9, 11, and 13, majority of students' perception towards assessment approach were assessment as learning. It means, students understood that result of assessment used to students to monitor and critically reflect their learning and identify next steps, reference point was personal goals and external standards, assessment goals were self-monitoring, self-corrections and adjustment, reasons of assessment is done for guide and give opportunity each students to monitor and critically reflect their learning and identify next steps, so information from result assessment used to describe accurately feedback for each students to develop their learning as their conditions, and assessment was done if each topics finish was accompanied lecturers' guiding and concealing. This perceptions were good assets to rich learning experience so enhancing students' professional outcome as expressed [4].

\section{CONCLUSION}

Based on amount of student who choose perception towards assessment approach and also score of questioner items, majority students choose assessment as learning. Based on amount of score respondent, majority student choose assessment of learning at number 4, 10 and 12 of questioner items. Based on amount of score respondent, majority student choose assessment for learning at number 1, 2. 3 and 8 of questioner items.

\section{REFERENCES}

[1] A. Hussain, "Canonical Correlational Models of Students' Perceptions of Assessment Task, Motivational Orientations, and Learning Strategies," International Journal of Instruction, Vol. 6, 2013.

[2] P. Black and D. William, "Assessment and Classroom Learning," Assessment in Education, vol. 5, 1998.

[3] P. Black and D. William, Raising Standards Through Classroom Assessment, King's College London School of Education, 2001.

[4] A. Davies, K. Patzopoulos, and K. Gray, "Emphasizing Assessment as Learning by Assessing Wiki Writing Assignments Collaboratively and Publicly Online," Australasian Journal of Educational Technology, Vol. 27, pp. 798-812, 2011.

[5] Dictionary, Oxford, Definition perception in English. Access at $26^{\text {th }}$ April 2017 from: https://en.oxforddictionaries.com/definition/perception.

[6] L. Earl, Assessment as Learning: Using Classroom Assessment to Maximize Student Learning, Thousand Oaks, CA: Corwin Press, 2003.

[7] K. Earl and D. Giles, "An-other Look at Assessment: Assessment in Learning,” New Zealand Journal of Teachers' Work, Vol. 8, pp. 11-20, 2011.

[8] L. Earl, and S. Katz, Rethinking Classroom Assessment with Purpose in Mind. Assessment for Learning, Assessment as Learning, Assessment of Learning, Western and Northern Canadian Protocol for Collaboration in Education

(WNCP).http://www.wncp.ca/media/40539/rethink.pdf

(2006).

[9] Enger, K. Sandra and R.E. Yager, Assessing Student Understanding in Science, Thousand Oaks, CA, Corwin Press, 2009.

[10] W. Harlen and R.D. Crick, "Testing and Motivation for Learning," Assessment in Education: Principles, Policy and Practice, 10, 2003.

[11] M. Hill, "Using Classroom Assessment for Effective Learning-Tension and Energies," The Curriculum Journal, 16(2), 2008.

[12] O'Farrell Ciara, Enhancing Student Learning Through assessment, access at $27^{\text {th }}$ April 2017, from: http://www.tcd.ie/teaching-learning/academicdevelopment/assets/pdf/250309_assessment_toolkit.pdf.

[13] Rowe Jessica, Assessment as Learning- ETEC 510, access at 2016; www.etec.ubc.ca/510wiki/Assessment_as_Learning\#Assessment__for Learning.

[14] Scouller, "The Influenced of Assessment Method on Students' Learning Approaches; Multiple Choice Question Examination Versus Assignment Essay," Higher Education, 35, 1998.

[15] B. Ussher and K. Earl, "Summative and Formative: Confused by the assessment terms," New Zealand Journal of Teacher Work, vol. 7, pp. 5363, 2010.

[16] W.G. Van, G. David, D. Filip, and R.J. Van Der, "Students' Assessment Preferences, Perceptions of Assessment and Their Relationships to Study Results," Higher Education, pp. 56-645, 2008.

[17] C. Liying, W.Y. Fei, and L. Xiaoqian, Chinese University Students' Perceptions of Assessment Task and Classroom Assessment Environment, Language Testing in Asia Springer, 2015.

[18] M. Tohir, H. Tariq, K. Mubashira, and A. Rabbia, "Impact of Formative Assessment on Academic Achievement of Secondary School Student," International Journal of Business and Social Science. Vol. 3, September 2012.

[19] Ministry of Education, Growing Success: Assessment, Evaluation and Reporting in Ontario School, 2010. Access at $25^{\text {th }}$ January 2017, from: http://www.edu.gov.on.ca. 